\title{
Occurrence of pathogenic microorganisms in dessert items collected from Dhaka city
}

\author{
Shohana Akter, Anasua Sarkar and Kamal Kanta Das* \\ Department of Microbiology, Stamford University Bangladesh, 51, Siddeswari Road, Dhaka-1217, Bangladesh
}

Received 21 August 2019/Accepted 30 September 2019

\begin{abstract}
Due to delicious taste and readily availability, desserts are one of the most popular foods in Dhaka city. High amount of carbohydrate and protein in dessert items make them more susceptible to proliferation of microbial growth. Present study depicted a complete microbiological profile of some popular desserts such as, sweet, pastry, ice cream, pudding, falooda, yogurt and custard available in different food shop at Dhaka city, Bangladesh. All the samples were found to be contaminated with heterotrophic bacteria as well as fungi within the range of $10^{3}$ to $10^{6} \mathrm{cfu} / \mathrm{g}$. In case of specific microflora, the growth of Staphylococcus spp., Klebsiella spp. and Pseudomonas spp. were observed in most of the samples indicates the poor quality of these products. Bioburdens of $E$. coli in sweet, pudding and yogurt were found in the range of $1.2 \times 10^{2}$ to $2.7 \times 10^{3} \mathrm{cfu} / \mathrm{g}$. Salmonella spp., Shigella spp. and Vibrio spp. could not be isolated from any of the samples. Current study indicates that hygienic conditions should be maintained during preparation, packaging and retailing of dessert items in order to reduce the load of contamination in ready to eat foods which will ensure good health of consumers.
\end{abstract}

Keywords: Dessert, Microbiological analysis, Consumer safety

\section{INTRODUCTION}

Desserts are one of the most common ready to eat food worldwide, most of them are milk based and others are made by mixing starch, sugar, salt, citric acid, gelatin and flavoring agents $(1,2)$. In Bangladesh, desserts like falooda, pudding and custard are available in different restaurants. Moreover, some items like cakes, ice creams are sold commercially. They are popular because they supply protein and energy instantly (3). Along with high nutritional value, contaminated desserts may cause serious food borne illness to consumers (4-7).

Many studies revealed that contaminated milk and milk based products are responsible for outbreaks of food borne disease (8-12). Milk based food like desserts can serve as an ideal growth medium for bacteria. Growth of pathogenic bacteria in these foods will be detrimental to health of children and immunocompromised persons when they consume such products in sufficient amount. Faulty pasteurized milk and contaminated raw materials are possible ways by which pathogens can get entry to final product (13).

In case of pastry or cake raw eggs are major source of contamination of pathogenic bacteria like Salmonella spp. (14-15). Some studies claim that outbreak of salmonellosis is associated with slightly cooked desserts using raw egg (14-16). Similarly, others pathogenic microbes can be get entry from different ingredients like custard powder, cream or sauces, nuts etc. (17). Higher moisture content, neutral $\mathrm{pH}$ and rich amount of nutrient make dessert excellent growth medium for many kinds of microorganisms (18). However, the microbial loads of food products are influenced by a number of factors such as the storage condition, raw materials used, processing environment, sanitary conditions, unhygienic handling packaging and storage (19).

Yeast and mold are the most common contaminants along with pathogenic bacteria like Escherichia coli, Staphylococcus aureus, Bacillus cereus, Campylobacter jejuni, Salmonella species, Listeria monocytogenes and some other pathogens (20). Presence of coliforms and $S$. aureus in desserts may be due to defective pasteurization, contaminated water or poor sanitary practices of handlers (1-2). $L$. monocytogenes, is another most common food borne illness causing microorganisms, may be associated with the consumption of pasteurized milk, cheese made from unpasteurized milk and other dairy based products (21-22).

Nearly 30 million foodborne illnesses are encountered every year in Bangladesh (32). To ensure public health safety, safe foods should be ensured for all consumers $(17,23)$. The aim of this research was to investigate the presence of microorganisms in common desserts available in Dhaka city.

\section{MATERIALS AND METHODS}

Study area, sampling and sample processing. Total sixteen desserts of different categories (sweet, pastry, ice cream, pudding, falooda, yogurt and custard) from two different locations (Baily Road and Mouchak) of Dhaka city were randomly collected following standard protocol (24). All the samples were quickly transported to the laboratory. Prior to microbiological assay, $10 \mathrm{~g}$ of each sample was homogenized with $90 \mathrm{ml}$ of normal saline in 9:1 ratio and serially diluted to $10^{-5}(4-7,25)$.

Microbiological analysis of each sample. A volume of $0.1 \mathrm{ml}$ from each sample suspension was spread onto nutrient agar (NA) and incubated at $37^{\circ} \mathrm{C}$ for $24 \mathrm{~h}$ for enumerating total viable bacteria (TVB). Sabouraud dextrose agar (SDA) (HiMedia Laboratories, Mumbai, India) was inoculated in the similar manner followed by incubation at $25^{\circ} \mathrm{C}$ for $48 \mathrm{~h}$ for the isolation of fungi (25).

Isolation of pathogenic microorganisms. For the isolation of coliform 
bacteria (Escherichia coli, Klebsiella spp.), $0.1 \mathrm{ml}$ of the each sample suspension was spread over MacConkey (HiMedia Laboratories, Mumbai, India) agar and incubated at $37^{\circ} \mathrm{C}$ for $24 \mathrm{~h}(4-7,25)$.

$0.1 \mathrm{ml}$ of each sample suspension was spread on Mannitol salt agar (MSA) (Oxoid Ltd., Basingstoke, Hampshire, England) for the estimation of Staphylococcus aureus and the plates were incubated at $37^{\circ} \mathrm{C}$ for $24 \mathrm{~h}$. For the estimation of starch hydrolyzing bacteria (Bacillus spp.), $0.1 \mathrm{ml}$ of each sample suspension was spread onto Starch agar (SA) (HiMedia Laboratories, Mumbai, India) and incubation at $37^{\circ} \mathrm{C}$ for $24 \mathrm{~h}$. For the enumeration of Pseudomonas spp., $0.1 \mathrm{ml}$ of each sample suspension was spread onto Pseudomonas agar (HiMedia Laboratories, Mumbai, India) and plates were incubated at $37^{\circ} \mathrm{C}$ for $24 \mathrm{~h}$. All the isolates were confirmed by biochemical examinations (Table 2).

Enrichment of Salmonella spp., Shigella spp. and Vibrio spp. Enrichment was performed for Salmonella spp. and Shigella spp. in Selenite Cystein Broth (SCB). $1.0 \mathrm{ml}$ of homogenized sample suspension was transferred to SCB followed by incubation at $37^{\circ} \mathrm{C}$ for $4 \mathrm{~h}$ and serial dilutions were made upto $10^{-3}$. From $10^{-3}$ dilution, $0.1 \mathrm{ml}$ was spread onto Salmonella Shigella (SS) agar (HiMedia Laboratories, Mumbai, India) followed by the incubation at $37^{\circ} \mathrm{C}$ for $24 \mathrm{~h}$. In case of Vibrio spp., $1.0 \mathrm{ml}$ of the homogenized sample suspension was transferred to alkaline peptone water (APW) and after incubated at $37^{\circ} \mathrm{C}$ for $4 \mathrm{~h}$, samples were serially diluted to $10^{-3}$. Then, $0.1 \mathrm{ml}$ of sample was speeded onto Thiosulfate Citrate Bile Salts Sucrose (TCBS) agar (HiMedia Laboratories, Mumbai, India) followed by the incubation at $37^{\circ} \mathrm{C}$ for $24 \mathrm{~h}(4-7,25)$.

\section{RESULTS}

Different studies on food products claim that processed foods are one of the most important portions of energy intake but contaminated food are serious threat to public health (26-28). So before declaring food as safe to consume, food should be compared with different food standard guidelines. In case of ready to eat foods, the maximum permissible limits for Total Plate Count (TPC) is $<10^{5} \mathrm{cfu} / \mathrm{g}$, yeast and mold is $<10^{4} \mathrm{cfu} / \mathrm{g}$, coliform bacteria $<200 / \mathrm{g}$ and E. coli should be absent (29-31).

Previously published many study on food samples claim that ready to eat foods of Bangladesh were contaminated with different microorganisms, among them $E$. coli was predominantly present in most of the cases (35). Present study found that, all the samples were contaminated with heterotrophic bacteria within the range of $10^{4}$ to $10^{6} \mathrm{cfu} / \mathrm{g}$ (Table 1). Comparing this result with food standard, three out of 16 samples exceed the microbial limit and only results from six samples were found to be satisfactory (below $10^{5}$ $\mathrm{cfu} / \mathrm{g}$ ). On the other hand, fungal load was within the range of $10^{2}$ to $10^{4} \mathrm{cfu} / \mathrm{g}$ which is under the recommended limit of fungus. Huge bacterial growth in desserts is a matter of concern as consumption of these food may lead to disease in many occasion.

In case of specific micro flora, the growth of Staphylococcus spp. was most predominated but $E$. coli, Klebsiella spp., Bacillus spp., and Pseudomonas spp. were also observed in many dessert samples. Staphylococcus spp. growth was found in ten samples with higher load up to $10^{3} \mathrm{cfu} / \mathrm{g}$. Unhygienic handling can be the possible cause of this contamination (1-3). Out of sixteen samples, five desserts mainly pudding and sweet were found to be contaminated with $E$. coli which is so alarming as it indicated the presence of others water borne pathogens. Six samples were found to be contaminated with Klebsiella spp. Use of contaminated water during preparation and washing are possible ways of transmission of these pathogens (33). Pseudomonas spp. is found in almost everywhere in the environment, but their presence in food is not acceptable (34). Six dessert samples were contaminated with Pseudomonas spp. (up to $10^{2}$ $\mathrm{cfu} / \mathrm{g}$ ). Spore forming bacteria like Bacillus spp. were

Table 1: Microbiological profile of some popular desserts

\begin{tabular}{|c|c|c|c|c|c|c|c|c|}
\hline $\begin{array}{l}\text { Collection } \\
\text { site }\end{array}$ & $\begin{array}{l}\text { Sample } \\
\text { name }\end{array}$ & TVB & $\begin{array}{l}\text { Total } \\
\text { Fungi }\end{array}$ & E. coli & $\begin{array}{l}\text { Klebsiella } \\
\text { spp. }\end{array}$ & Bacillus spp. & $\begin{array}{c}\text { Pseudomonas } \\
\text { spp. }\end{array}$ & $\begin{array}{c}\text { Staphylococcus } \\
\text { spp. }\end{array}$ \\
\hline \multirow{8}{*}{ Baily Road } & Sweet & $1.7 \times 10^{6}$ & $2.7 \times 10^{3}$ & $3.7 \times 10^{3}$ & 0 & 0 & 0 & $2.8 \times 10^{3}$ \\
\hline & $\begin{array}{l}\text { Normal } \\
\text { Pastry }\end{array}$ & $1.2 \times 10^{4}$ & $1.7 \times 10^{2}$ & 0 & $1.1 \times 10^{2}$ & 0 & $1.1 \times 10^{2}$ & $1.6 \times 10^{3}$ \\
\hline & $\begin{array}{c}\text { Chocolate } \\
\text { Pastry }\end{array}$ & $2.3 \times 10^{4}$ & $2.0 \times 10^{2}$ & 0 & 0 & & $1.8 \times 10^{2}$ & 0 \\
\hline & Ice cream & $2.0 \times 10^{4}$ & $1.5 \times 10^{2}$ & 0 & 0 & & 0 & $2.0 \times 10^{2}$ \\
\hline & Pudding & $3.0 \times 10^{5}$ & $1.2 \times 10^{2}$ & $1.2 \times 10^{2}$ & 0 & 0 & 0 & $3.1 \times 10^{2}$ \\
\hline & Falooda & $2.1 \times 10^{5}$ & $2.2 \times 10^{2}$ & 0 & $1.3 \times 10^{2}$ & $1.1 \times 10^{2}$ & $2.1 \times 10^{2}$ & 0 \\
\hline & Yoghurt & $4.5 \times 10^{6}$ & $2.3 \times 10^{3}$ & 0 & $1.2 \times 10^{2}$ & 0 & 0 & 0 \\
\hline & Custard & $4.1 \times 10^{5}$ & $1.9 \times 10^{2}$ & 0 & $2.1 \times 10^{2}$ & 0 & 0 & $2.8 \times 10^{2}$ \\
\hline \multirow{8}{*}{ Mouchak } & Sweet & $2.0 \times 10^{5}$ & $2.7 \times 10^{2}$ & $1.2 \times 10^{3}$ & 0 & 0 & 0 & $2.8 \times 10^{3}$ \\
\hline & $\begin{array}{l}\text { Normal } \\
\text { Pastry }\end{array}$ & $1.8 \times 10^{3}$ & $1.7 \times 10^{2}$ & 0 & 0 & 0 & $1.2 \times 10^{2}$ & $1.0 \times 10^{2}$ \\
\hline & $\begin{array}{c}\text { Chocolate } \\
\text { Pastry }\end{array}$ & $2.1 \times 10^{4}$ & $2.0 \times 10^{2}$ & 0 & 0 & 0 & $1.4 \times 10^{2}$ & 0 \\
\hline & Ice cream & $2.4 \times 10^{4}$ & $1.5 \times 10^{3}$ & 0 & 0 & & 0 & $2.0 \times 10^{2}$ \\
\hline & Pudding & $3.1 \times 10^{5}$ & $1.2 \times 10^{2}$ & $1.2 \times 10^{2}$ & 0 & 0 & 0 & $1.9 \times 10^{2}$ \\
\hline & Falooda & $3.2 \times 10^{5}$ & $2.2 \times 10^{2}$ & 0 & $1.3 \times 10^{2}$ & $1.1 \times 10^{2}$ & $1.7 \times 10^{2}$ & 0 \\
\hline & Yoghurt & $2.9 \times 10^{6}$ & $2.1 \times 10^{4}$ & $1.2 \times 10^{2}$ & 0 & 0 & 0 & 0 \\
\hline & Custard & $3.0 \times 10^{5}$ & $2.0 \times 10^{2}$ & 0 & $1.1 \times 10^{2}$ & $1.3 \times 10^{2}$ & 0 & $2.2 \times 10^{2}$ \\
\hline
\end{tabular}

*Salmonella spp., Shigella spp. and Vibrio spp. were totally absent.

Microbial limit. Total plate count (TPC) or Total Viable Bacteria (TVB) is $<10^{5} \mathrm{cfu} / \mathrm{g}$, yeast and mold are $<10^{4} \mathrm{cfu} / \mathrm{g}$, coliform bacteria $<200 /$ g, and E. coli should be absent. 
Tables 2: Confirmative biochemical tests for the isolates

\begin{tabular}{|c|c|c|c|c|c|c|c|c|c|c|}
\hline \multirow{2}{*}{$\begin{array}{l}\text { Assumed } \\
\text { Organism }\end{array}$} & \multicolumn{3}{|c|}{ TSI } & \multirow{2}{*}{ 胥 } & \multirow{2}{*}{$\frac{\ddot{\Xi}}{\stackrel{\Xi}{\Xi}}$} & \multirow{2}{*}{ 号苞 } & \multirow{2}{*}{$\begin{array}{l}\overrightarrow{v^{2}} \\
\stackrel{5}{5}\end{array}$} & \multirow{2}{*}{$\stackrel{\vec{E}}{\vec{E}}$} & \multirow{2}{*}{ 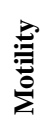 } & \multirow{2}{*}{ 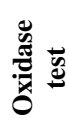 } \\
\hline & slant & butt & gas & & & & & & & \\
\hline E. coli & $\mathrm{Y}$ & $\mathrm{Y}$ & + & - & + & + & - & - & + & \\
\hline Klebsiella spp. & $\mathrm{Y}$ & $\mathrm{Y}$ & - & - & - & - & - & - & - & + \\
\hline Pseudomonas spp. & $\mathrm{R}$ & $\mathrm{R}$ & - & - & - & - & - & + & - & - \\
\hline Staphylococcus spp. & $\mathrm{Y}$ & $\mathrm{R}$ & + & + & - & + & - & + & + & - \\
\hline
\end{tabular}

TSI = Triple Sugar Iron Test; $\mathrm{Y}=$ Yellow (Acid); R = Red (Alkaline); MR = Methyl Red; VP = Voges-Proskauer

also encountered in three samples with the load of $10^{2}$ $\mathrm{cfu} / \mathrm{g}$.

Huge amount of microbes in ready to eat food is not acceptable as they are consumed without any further processing and current condition may be due to lack of knowledge about hygienic in consumers, use of contaminated equipment and dirty processing area. In present study, commercially available foods (sweet, pastry, ice cream) containing less microbial load than handmade food (sweet, pudding, falooda, yogurt and custard), indicates the unhygienic handling or poor environmental conditions.

\section{CONCLUSION}

Cross-contamination of foods is one of the major concerns in the food industry, and if microorganisms are not completely removed from food-contact surfaces, they may form biofilms and also increase the bio-transfer potential. This study demonstrates the presence of some pathogens including Staphylococcus spp. and E. coli in dessert items. Therefore, from the public health point of view, these foods offer serious threat for the consumers. Presence of contaminating microorganisms indicates the poor hygienic conditions during the manufacturing, storage and sales process of these traditional foods. Manufacturing procedures within the scope of the HACCP, appropriate hygienic measures to avoid processing and post processing cross contamination and the use of properly pasteurized milk are critical for controlling these pathogens in dessert items.

\section{REFERENCES}

1. De Wijk RA, Van-Gemert LJ, Terpstra, MEJ and Wilkinson CL. 2003. Texture of semi-solids, sensory and instrumental measurements on vanilla custard desserts. Food Qual. Prefer. 14:305-317.

2. González-Tomás L and Costell E. 2006. Relation between consumers perception of color and texture of dairy desserts and instrumental measurements using generalized procrustes analysis. J. Dairy Sci. 89:4511-4519.

3. Chaudhari SN, Palve SB, Choudhari KR, Pawar DH and Gaikwad SS 2017. Microbial Analysis of Ragi Cake Base Stored at Room Temperature without Added Chemical Preservative. Int. J. Curr. Microbiol. App. Sci. 6:3519-3525.

4. Ahmed T, Baidya S, Sharma BC, Malek M, Das KK, Acharjee M, et al 2013. Identification of drug-resistant bacteria among export quality shrimp samples in Bangladesh. Asian J. Microbiol. Biotech. Env. Sci. 15:31-36.

5. Khanom A, Shammi T and Kabir MS. 2016. Determination of microbiological quality of packed and unpacked bread. Stam. J. Microbiol. 6:24-29.
6. Noor R, Acharjee M, Ahmed T, Das KK, Paul L, Munshi SK et al. 2013. Microbiological analysis of major sea fish collected from local markets in Dhaka city, Bangladesh. J. Micro. Biotech. Food Sci. 2:2420-2430.

7. Rahman H, Feroz F, Alam MS, Das KK and Noor R. 2016. Demonstration of the source of microbial contamination of freshly cultivated cabbage, cauliflower, potato and squash collected from rural farms of Bangladesh. Int. Food Rese. J. 23:1289-1295.

8. Danielsson-Tham ML, Eriksson E, Helmersson S, Leffler M, Ludtke L and Steen M. 2004. Causes behind a human cheese-borne outbreak of gastrointestinal listeriosis. Food borne Pathog. Dis. 1:153-159.

9. MacDonald PD, Whitwam RE, Boggs JD, MacCormack JN, Anderson KL and Reardon JW. 2005. Outbreak of Listeriosis among Mexican immigrants as a result of consumption of illicitly produced Mexicanstyle cheese. Clin. Infect. Dis. 40:677-82

10. Makino SI, Kawamoto K, Takeshi K, Okada Y, Yamasaki M and Yamamoto S. 2005. An outbreak of food-borne Listeriosis due to cheese in Japan, during 2001. Int. J. Food Microbiol. 104:189-96.

11. Okwumabua O, O'Connor M, Shull E, Strelow K, Hamacher M and Kurzynski T. 2005. Characterization of Listeria monocytogenes isolates from food animal clinical cases: PFGE pattern similarity to strains from human listeriosis cases. FEMS Microbiol. Lett. 249:275-81.

12. Oliver SP, Jayarao BM and Almeida RA. 2005. Food-borne pathogens in milk and the dairy farm environment: food safety and public health implications. Foodborne. Pathog. Dis. 2:115.

13. Food safety authority of Ireland. Survey of the microbiological safety of ready-to-eat cakes, pastries and desserts with high-risk fillings (14NS1). Monitoring \& Surveillance Series, June 2018.

14. Sarna M, Dowse G, Evans G and Guest C. 2002. An outbreak of Salmonella typhimurium PT135 gastroenteritis associated with a minimally cooked dessert containing raw eggs. Communi. Dis. Intellig. 26:32-37.

15. Ward B, Andrews R, Gregory J and Lightfoot D. 2002. The use of sequential studies in a salmonellosis outbreak linked to continental custard cakes. Epidem. Infec. 129:287-293.

16. Calvert N, Murphy L, Smith A. and Copeland D. 2007. A hotel-based outbreak of Salmonella enterica subsp. Enterica serovar Enteritidis (Salmonella enteritidis) in the United Kingdom, 2006. Eur. commun. dis. bulletin 12:222

17. El-Fadaly H, El-Kadi S and El-Gaya E. 2016. Microbiological examination for some chocolate cake samples. J. Env. Sci. 45:11-27.

18. Siriken B, Cadirci O, Inat G and Pamuk S. 2009. Microbiological Examination of Meatball, Cream Cake and Turkish Delight (Lokum). J. Ani. Veter. Adv. 8:2049-2054.

19. Osamwonyi OU. 2005. Occurrence of coliforms in ice cream. Dept. of Microbiology, University of Benin. Bs.c. Thesis:pp65.

20. Amani P, Lindbom I, Sundström B and Östergren K. 2015. Green-Lean Synergy - Root-Cause Analysis in Food Waste Prevention. Int. J. Food Sys. Dyn, 6:99-109.

21. Kells J and Gilmour A. 2004. Incidence of Listeria monocytogenes in two milk processing environments and assessment of Listeria monocytogenes blood agar for isolation. Int. J. Food Microbiol. 91:16774.

22. Manfreda G, De Cesare A, Stella S, Cozzi M and Cantoni C. 2005. Occurrence and ribo types of Listeria monocytogenes in Gorgonzolla cheese. Int. J. Food Microbiol. 102:287-93.

23. Easa MSH. 2010. The microbial quality of fast food and traditional fast food. Nat. Sci. 8:117-133

24. A.P.H.A. 1992. Standard Methods for the Examination of Dairy Products. $13^{\text {th }}$ Ed., American Public Health Association. Academic Press:2062-2065.

25. Cappuccino JG and Sherman N. 2001. Microbiology; laboratory manuals, $7^{\text {th }}$ ed, by Alexander / strete; Benjamin / Cummings, USA 2001.

26. Vanelli M, Iovane B, Bernardini A, Chiari G, Errico MK, Gelmetti C et al. 2005. Breakfast habits of 1,202 northern Italian children admitted to a summer sport school. Breakfast skipping is associated with overweight and obesity. Acta Biomed. Ateneo. Parmense. 76:79-85. 
27. Bartrina AJ, Rodrigo PC, Majem SL and Rubio DA. 2004. Food habits of students using school dining rooms in Spain. "Tell Me How You Eat" Study. Aten. Primaria. 33:131-139.

28. Agte V, Tarwadi K, Mengale S, Hinge A and Chiplonkar S. 2002. Vitamin profile of cooked foods: how healthy is the practice of ready-toeat foods? Int. J. Food Sci. Nutr. 53:197-208.

29. Gilbert RJ, de Louvois J, Donovan T, Little C, Nye K and Ribeiro CD et al. 2000. Guidelines for the microbiological quality of some ready-to-eat foods samples at the point of sale. Commun. Dis. Public Health. 3:163 167.

30. Hocking AD. 2003. Foodborne Microorganisms of Public Health Significance, $6^{\text {th }}$ ed. Waterloo, N.S.W.: Australian Institute of Food Science and Technology, (NSW Branch) Food Microbiology Group.

31. WHO. 1994. Guideline value for food and drinking water, World Health
Organization, Geneva.

32. Khairuzzaman M, Chowdhury FM, Zaman S, Mamun AA and Bari ML. 2014. Food safety challenges towards safe, healthy, and nutritious street foods in Bangladesh. Int. J. Food Sci. 2014: Article ID 483519.

33. Alam MS, Feroz F, Rahman S, Das KK and Noor R 2015. Microbiological contamination sources of freshly cultivated vegetables. Nut. Food Sci. 45:646-658

34. International Commission on Microbiological Specification of Food (ICMSF). 2002. Microorganisms in Foods 7. Microbiological testing in food safety management. Kluwer Academic/Plenum Publishers, New York, USA

35. Banik A, Abony M, Suvamoy Datta S and Towhid ST. 2019. Microbiological Quality of Ready - to - Eat Food from Dhaka, Bangladesh. Curr. Res. Nut. Food Sci. 7:161-168. 